\title{
The Relationship Between Warfarin Resistance and CYP2C9*2 and CYP2C9*3 Variations
}

\section{Varfarin Direnci CYP2C9*2 ve CYP2C9*3 Varyasyonlarıla İlişkili Olabilir}

\author{
(D) Deniz Kıraç1', (1) Aysun Erdem Yaman², (1) Tansu Doran¹, (1) Elif Çiğdem Altunok³ \\ ${ }^{1}$ Yeditepe University Faculty of Medicine, Department of Medical Biology, İstanbul, Turkey \\ ${ }^{2}$ Dr. Siyami Ersek Thoracic and Cardiovascular Surgery Training and Research Hospital, Clinic of Cardiology, İstanbul, Turkey \\ ${ }^{3}$ Yeditepe University Faculty of Medicine, Department of Biostatistics and Medical Informatics, İstanbul, Turkey
}

\begin{abstract}
Objective: Warfarin is one of the most widely used anticoagulants worldwide. Some patients need $>15 \mathrm{mg} /$ day of warfarin to get their therapeutic international normalized ratio (INR). This condition is known as warfarin resistance (WR). WR is related to enzyme deficiencies, which play a role in warfarin metabolism. One of the most important enzyme-related drug metabolism is the cytochrome P450, family 2, subfamily C, member 9 (CYP2C9). Therefore, this study aimed to investigate the relationship between CYP2C9 variations and WR.

Methods: To find patients with WR, 650 patients who used warfarin for at least 6 months were screened. Then, patients were grouped into two according to the INR values, wherein 30 patients with INR levels not reaching the therapeutic range $(<2)$ despite using 15 mg of warfarin per day were included in the non-responder group and 30 randomly selected patients who received low-dose warfarin, whose INR levels were within the therapeutic range (2-3), were included in the responder group. After the genomic deoxyribonucleic acid isolation from the peripheral blood, CYP2C9*2 and CYP2C9*3 variations were investigated using the real-time polymerase chain reaction. Results were statistically evaluated.

Results: Heterozygous genotype of CYP2C9*3 was statistically high in responders (33.3\%), whereas the wild-type genotype was statistically high in nonresponders (90\%) (p<0.05). In addition, the T allele of CYP2C9*2 $(18.3 \%)$ and the C allele of CYP2C9*3 (16.7\%) were statistically high in responders $(p<0.05)$.

Conclusion: Patients with gene variations that reduced the CYP2C9 activity are termed poor metabolizers. These individuals metabolize warfarin more slowly and require smaller doses of the drug to reach the therapeutic INR values. Therefore, adjusting the warfarin dose is possible depending on the genotype of patients.
\end{abstract}

Keywords: Warfarin resistance, CYP2C9, RT-PCR

\section{Öz}

Amaç: Varfarin, dünyada en yaygın kullanılan antikoagülanlardan biridir. Bazı hastalar, uluslararası normalize oranlarını (INR) terapötik aralığa getirmek için günde 15 mg'dan fazla varfarine ihtiyaç duyar. Bu durum, varfarin direnci (VD) olarak bilinir. VD, varfarin metabolizmasında rol oynayan enzim eksiklikleri ile ilişkili olabilir. Illaç metabolizması ile ilgili en önemli enzimlerden biri sitokrom P450, aile 2, alt aile C, üye 9'dur (CYP2C9). Bu nedenle bu çalışmada, VD ile CYP2C9 varyasyonları arasındaki ilişkinin araştırııması amaçlanmıştır.

Gereç ve Yöntem: VD olan hastaları bulabilmek için en az 6 ay varfarin kullanan 650 hasta tarandı. Daha sonra hastalar içerisinden INR değerlerine göre 2 grup oluşturmak için hasta seçimi yapıldı. Günde 15 mg varfarin kullanmasına rağmen INR düzeyi terapötik aralığa gelmeyen (<2) 30 kişi ilaca yanıt vermeyen gruba, düşük doz varfarin kullanarak INR düzeyleri terapötik aralığa (2-3) gelen ve tüm hastalar arasından rastgele seçilen 30 hasta ise tedaviye yanıt veren gruba dahil edildi. Periferik kandan genomik DNA izole edildikten sonra, CYP2C9*2 ve CYP2C9*3 varyasyonları gerçek zamanlı polimeraz zincir reaksiyonu (GZ-PZR) kullanılarak araştııldı. Sonuçlar istatistiksel olarak değerlendirildi.

Bulgular: Tedaviye yanıt veren grupta CYP2C9*3 heterozigot genotipinin (\%33.3), tedaviye yanıt vermeyen grupta ise yabani tip genotipin istatistiksel olarak yüksek olduğu (\%90) belirlendi $(p<0,05)$. Ek olarak, tedaviye yanıt veren grupta CYP2C9*2T alleli $(\% 18.3)$ ve CYP2C9*3 C alleli $(\% 16,7)$ istatistiksel olarak yüksek bulundu $(p<0,05)$.

Address for Correspondence: Deniz Kıraç, Yeditepe University Faculty of Medicine, Department of Medical Biology, İstanbul,

Turkey

Phone: +90 5424855292 E-mail: denizyat@hotmail.com ORCID ID: orcid.org/0000-0002-3599-7344

Cite as: Kıraç D, Erdem Yaman A, Doran T, Altunok EÇ. The Relationship Between Warfarin Resistance and CYP2C9*2 and CYP2C9*3 Variatıons. Med J Bakirkoy 2021;17:209-213

Received: 20.04 .2021

Accepted: 20.09.2021 
Sonuç: Hastalarda CYP2C9 aktivitesinde azalmaya neden olan gen varyasyonları varsa, bunlar zayıf metabolize ediciler olarak adlandırılır. Bu kişiler, varfarini daha yavaş metabolize ederler ve terapötik INR değerlerine ulaşmak için daha küçük dozlarda ilaca ihtiyaç duyarlar. Bu nedenle hastaların genotipine bağlı olarak varfarin dozunun ayarlanması mümkündür.

Anahtar Kelimeler: Varfarin direnci, CYP2C9, GZ-PZR

\section{INTRODUCTION}

Atrial fibrillation (AF) is one of the most known abnormal heart rhythm disorders that affects $>30$ million people worldwide. Patients with a high risk of AF usually take anticoagulants, such as warfarin (1). The risk of embolism, especially the risk of ischemic stroke, increases in AF associated with thrombus formation in the left atrium (2). Pulmonary embolism (PE) is a life-threatening condition and is one of the most common causes of cardiovascular death, which is a known complication of deep venous thromboembolism (DVT) $(3,4)$. Mechanical heart valves are implanted in patients with long life expectancy, which are more durable than bioprostheses. However, the disadvantage is the lifelong requirement of anticoagulants, such as warfarin, due to their higher thrombogenicity (5).

Warfarin is one of the most used anticoagulants worldwide, which reduces vitamin $\mathrm{K}$ formation by inhibiting vitamin $\mathrm{K}$ epoxide reductase, a multiprotein enzyme complex that activates vitamin K. Prothrombin and clotting factors VII, IX, and $\mathrm{X}$ have reduced coagulation ability without adequate active vitamin $\mathrm{K}$. Anticoagulant protein $\mathrm{S}$ and $\mathrm{C}$ are also inhibited in this process. Thus, blood clotting decreases (6). Age, gender, body mass index, smoking, drug therapy, concurrent hepatic or renal disease, and dietary vitamin $\mathrm{K}$ intake also play a role in warfarin metabolism (7-9).

The international normalized ratio (INR), developed by the World Health Organization in the early 1980s, is widely used to monitor oral anticoagulation and evaluate patients with coagulation disorders, which was designed to eliminate problems in oral anticoagulants (10). It is the test of choice for patients taking vitamin $\mathrm{K}$ antagonists (VKA). INR is also used to assess patients' risk of coagulation or bleeding. Patients receiving oral anticoagulants need to monitor the INR values to adjust their VKA dose, as this value differs between patients (11). INR value is around 1 in healthy individuals. INR ratio differs according to each disease. INR value should be between 2-3 in patients with cerebro-cardiovascular occlusion or with DVT/PE and 2.53.5 in patients with heart rhythm disorders, such as heart valve disease or AF (12). Patients usually receive $5 \mathrm{mg}$ of warfarin daily; however, some patients require $>15 \mathrm{mg}$ of warfarin daily to get the INR value into the therapeutic range. This condition is defined as warfarin resistance (WR)
(13). WR is associated with enzyme deficiencies involved in warfarin metabolism (14). cytochrome P450, family 2, subfamily C, member (CYP2C9) is one of the cytochrome p450 enzymes involved in the metabolism of many drugs, which is also involved in warfarin metabolism (15). CYP2C9*2 and $C Y P 2 C 9 * 3$ variations are frequently encountered in the CYP2C9 gene encoding the CYP2C9 enzyme. CYP2C9*2 (rs1799853) variation causes Arg144Cys amino acid change due to a C430T nucleotide change in exon 3. CYP2C9*3 (rs1057910) variation causes Ile359Leu amino acid change due to the $\mathrm{A} 1075 \mathrm{C}$ nucleotide change in exon 7. Both variations decrease enzymatic activities (16). The variations in the CYP2C9 gene are associated with WR, thus this study aimed to investigate the relationship between the CYP2C9 gene variations and WR.

\section{METHODS}

\section{Study Population}

WR is a rare condition. Therefore, 650 patients who applied to the cardiology clinic of Haydarpaşa Numune Training and Research Hospital and used warfarin for at least 6 months and had AF, mechanical aortic prosthetic valve, and DVT or PE were screened to find those with WR. Then, patients were grouped into two according to the INR values, wherein 30 patients, whose INR level did not reach the therapeutic range $(<2)$ despite using $15 \mathrm{mg}$ of warfarin per day, were included in the non-responder group and 30 randomly selected patients who received low-dose warfarin, with INR levels within the therapeutic range (2-3) were included in the responder group. Patients who have liver disease, heart failure, or hematologic disorders were excluded from the study. Patients who used aspirin, non-steroidal antiinflammatory drugs, antifungals (fluconazole), antibiotics, statin group drugs, tricyclic antidepressants, and thyroid drugs within the last week were excluded from the study, together with those alcoholic and pregnant. The study, which is compatible with the Helsinki Declaration, was approved by the Clinical Research Ethics Committee of Haydarpaşa Numune Training and Research Hospital (approval date: december 30, 2019; approval number: 2019/166-1096). Each individual was informed about the study and written informed consent was obtained from each participant. 


\section{Blood Sampling and Genotyping}

Whole blood samples were obtained from all patients. Deoxyribonucleic acid (DNA) was extracted from 200 $\mu \mathrm{L}$ of peripheral blood using commercially available kits (Qiagen, Foster City, USA) according to the manufacturer's instructions. DNA purity and concentrations were determined by NanoDrop spectrophotometer (Thermo Scientific, Wilmington, USA). Real-time polymerase chain reaction (RT-PCR) reactions for CYP2C9*2 and CYP2C9*3 were carried out on 7500 fast RT-PCR System (Applied Biosystems). The reaction was performed according to the manufacturer's instructions.

\section{Statistical Analysis}

Statistical Package for the Social Science 25.0 was performed for statistical analysis (IBM Corp. released 2017, IBM SPSS Statistics for Windows. Armonk, NY: IBM Corp.). Continuous variables are expressed as mean \pm standard deviation and discrete variables are expressed as counts or percentages. Normal distribution assumption was checked with the Kolmogorov-Smirnov test. Two independent samples t-test was used to compare continuous variable means between two groups, which were normally distributed. The KruskalWallis tests were performed to investigate the difference between genotypes and risk factors (which are not normally distributed). The Mann-Whitney $U$ test was performed for pairwise comparison in statistically significant differences, and Bonferroni correction was applied to the $p$-values. The $p$-values of $<0.05(p<0.05)$ were considered statistically significant.

\section{RESULTS}

\section{Study Population}

The demographic characteristics of patients are shown in Table 1. Demographic characteristics comparison between groups revealed a statistically significant relationship between age and INR values.

\section{CYP2C9 Genotyping}

Table 2 shows the nucleotide distributions among the groups. The genotype distribution comparison between the groups revealed a statistically high heterozygous genotype of CYP2C9*3 $(33.3 \%)$ in responders, whereas a statistically high wild-type genotype was found in nonresponders $(90 \%)(p<0.05)$.

\section{Allele Frequencies of CYP2C9 Variations}

Table 3 shows the allele frequencies of groups. The group comparison in terms of allele frequencies revealed a statistically high T allele of CYP2C9*2 (18.3\%) and C allele of CYP2C9*3 (16.7\%) in responders $(p<0.05)$.
Table 1. Demographic characteristics of patients

\begin{tabular}{|c|c|c|c|c|}
\hline \multirow{2}{*}{\multicolumn{2}{|c|}{$\begin{array}{l}\text { Demographic } \\
\text { characteristics }\end{array}$}} & \multicolumn{2}{|l|}{ Groups } & \multirow[b]{2}{*}{$p$} \\
\hline & & $\begin{array}{l}\text { Non- } \\
\text { responders } \\
(n=30)\end{array}$ & $\begin{array}{l}\text { Responders } \\
(n=30)\end{array}$ & \\
\hline \multicolumn{2}{|l|}{ Age (year) } & $53.17 \pm 13.48$ & $66.4 \pm 12.46$ & $<0.001^{\star *}$ \\
\hline \multicolumn{2}{|c|}{ Average INR value } & $1.96 \pm 0.39$ & $2.59 \pm 0.24$ & $<0.001^{\text {** }}$ \\
\hline \multirow{3}{*}{$\begin{array}{l}\text { Warfarin } \\
\text { indication }\end{array}$} & $\begin{array}{l}\text { Atrial } \\
\text { fibrillation }\end{array}$ & 11 & 18 & \multirow{3}{*}{0.118} \\
\hline & $\begin{array}{l}\text { Deep vein } \\
\text { thrombosis } \\
\text { or } \\
\text { pulmonary } \\
\text { embolism }\end{array}$ & 6 & 6 & \\
\hline & $\begin{array}{l}\text { Mechanical } \\
\text { aortic } \\
\text { prosthetic } \\
\text { valve }\end{array}$ & 13 & 6 & \\
\hline \multirow{2}{*}{ Gender } & Female & 21 & 17 & \multirow{2}{*}{0.284} \\
\hline & Male & 9 & 13 & \\
\hline
\end{tabular}

${ }^{\star \star} \mathrm{p}<0.001$, INR: International normalized ratio

Table 2. Distribution of nucleotide variations between groups

\begin{tabular}{|c|c|c|c|}
\hline \multirow{2}{*}{$\begin{array}{l}\text { Genes, } \\
\text { genotypes, } \\
\text { nucleotide } \\
\text { variations }\end{array}$} & \multicolumn{2}{|l|}{ Groups } & \multirow[b]{2}{*}{$p$} \\
\hline & $\begin{array}{l}\text { Non-responders } \\
(n=30)\end{array}$ & $\begin{array}{l}\text { Responders } \\
(n=30)\end{array}$ & \\
\hline \multicolumn{4}{|l|}{ CYP2C9*2 } \\
\hline $\mathrm{CC}$ & $27(90 \%)$ & 22 (73.3\%) & \multirow{3}{*}{0.135} \\
\hline CT & $3(10 \%)$ & 5 (16.7\%) & \\
\hline TT & 0 (2.8\%) & $3(10 \%)$ & \\
\hline \multicolumn{4}{|l|}{ CYP2C9*3 } \\
\hline $\mathrm{AA}$ & *27 (90\%) & $20(66.7 \%)$ & \multirow{3}{*}{$0.029 *$} \\
\hline$A C$ & $3(10 \%)$ & *10 (33.3) & \\
\hline $\mathrm{CC}$ & $0(0 \%)$ & $0(0)$ & \\
\hline
\end{tabular}

Table 3. Allele frequencies of groups

\begin{tabular}{|c|c|c|c|}
\hline \multirow[b]{2}{*}{ Alleles } & \multicolumn{2}{|l|}{ Groups } & \multirow[b]{2}{*}{$p$} \\
\hline & $\begin{array}{l}\text { Non-responders } \\
(n=30)\end{array}$ & $\begin{array}{l}\text { Responders } \\
(n=30)\end{array}$ & \\
\hline \multicolumn{4}{|c|}{ CYP2C9*2 } \\
\hline C & 57 (95\%) & 49 (81.7\%) & \multirow{2}{*}{$0.012^{*}$} \\
\hline $\mathrm{T}$ & $3(5 \%)$ & *11 (18.3\%) & \\
\hline \multicolumn{4}{|c|}{ CYP2C9*3 } \\
\hline A & 57 (95\%) & 50 (83.3\%) & \multirow{2}{*}{$0.037^{*}$} \\
\hline C & $3(5 \%)$ & *10 (16.7\%) & \\
\hline${ }^{*} p<0.05$ & & & \\
\hline
\end{tabular}




\section{DISCUSSION}

Warfarin is frequently used for venous thromboembolism treatment after mechanical heart valve implantation and thromboembolic complication prevention in AF (15). It is metabolized by CYP2C9, one of the cytochrome P450 enzymes, to the 7-hydroxylated form. Many variants were identified in the CYP2C9 gene which encodes the CYP2C9 enzyme. CYP2C9*2 and CYP2C9*3 are best-characterized variations of CYP2C9 (13). Individuals with CYP2C9*2 and CYP2C9*3 genotypes have $12 \%$ and $5 \%$ lower enzyme activity than the wild type, respectively, and are prone to bleeding after warfarin treatment (17). CYP2C9*2 reduced warfarin metabolism by $30 \%$ and CYP2C9*3 by $80 \%$ compared with CYP2C9*1, which is a wild-type variant of CYP2C9 (18). Individuals carrying the CYP2C9*2 and CYP2C9*3 variants reach the targeted INR level with lower amounts of warfarin (13). Ozer et al. (19) found that individuals with the CYP2C9*1*1 genotype had a higher daily warfarin dose than those with the ${ }^{*}{ }^{*} 3 /{ }^{*} 23$ genotype. The same study revealed a similar result of undetected $* 1 * 2$ genotype. Another study revealed no significance between the WR and CYP2C9 variations (13). Dilge Taşkın et al. (18) showed that CYP2C9 variants were detected at the rates of *1/*1 $(54.6 \%), * 1 / * 2(16.4 \%), * 1 / * 3(24.2 \%), * 2 / * 3(2.9 \%)$, and $* 3 / * 3(1.9 \%)$. The same study concluded that patients with variations needed lower warfarin doses (18). Another study found that CYP2C9*2 and CYP2C9*3 variations of CYP2C9 decrease the rates of warfarin clearance. Another study found a significant association between CYP2C9*3 with warfarin therapy (20). The allele frequency comparison between the groups in our study revealed a statistically high T allele in CYP2C9*2 (18.3\%) and C allele in CYP2C9*3 $(16.7 \%)$ in responders $(p<0.05)$. In addition, the genotype distribution comparison between the groups revealed a statistically high CYP2C9*3 (33.3\%) variation in responders $(p<0.05)$. The wild-type genotype of CYP2C9*3 was significantly high in nonresponders $(p<0.05)$.

The limitation of our study is the small number of patients $(n=60)$. However, considering that WR is an extremely rare condition, it is acceptable to screen approximately 650 patients and include 30 patients with WR in the study.

\section{CONCLUSION}

In conclusion, individuals with CYP2C9 homozygous wild-type genotype required higher daily warfarin dose compared to the *2 and *3 variants. Particularly, patients with gene variations reduced CYP2C9 activity, which is termed as poor metabolizers. These individuals metabolize warfarin more slowly and require smaller doses of the drug to reach the therapeutic INR values. Therefore, adjusting the warfarin dose is possible depending on the genotype of patients.

\section{ETHICS}

Ethics Committee Approval: The study, which is compatible with the Helsinki Declaration, was approved by the Clinical Research Ethics Committee of Haydarpaşa Numune Training and Research Hospital (approval date: december 30, 2019; approval number: 2019/166-1096).

Informed Consent: All patients and/or legal guardians included in the study provided their written informed consent.

\section{Authorship Contributions}

Surgical and Medical Practices: A.E.Y., Concept: D.K., A.E.Y., Design: D.K., A.E.Y., E.Ç.A., Data Collection or Processing: D.K., A.E.Y., T.D., E.Ç.A., Analysis or Interpretation: D.K., A.E.Y., T.D., E.Ç.A., Literature Search: D.K., T.D., Writing: D.K., T.D., E.Ç.A.

Conflict of Interest: No conflict of interest was declared by the authors.

Financial Disclosure: The authors declared that this study received no financial support.

\section{REFERENCES}

1. Deng $Y$, Tong $Y$, Deng $Y$, Zou L, Li S, Chen H. Non-Vitamin K Antagonist Oral Anticoagulants Versus Warfarin in Patients With Cancer and Atrial Fibrillation: A Systematic Review and MetaAnalysis. J Am Heart Assoc 2019;8:e012540.

2. Enga KF, Rye-Holmboe I, Hald EM, Løchen ML, Mathiesen $E B, N j ø l s t a d$ I, et al. Atrial fibrillation and future risk of venous thromboembolism:the Tromsø study. J Thromb Haemost 2015;13:10-6.

3. Waleed KB, Guan X, Li X, YangY, WangZ, Yin X et al. Atrial fibrillation is related to lower incidence of deep venous thrombosis in patients with pulmonary embolism. J Thorac Dis 2018;10:1476-82.

4. Ptaszynska-Kopczynska K, Kiluk I, Sobkowicz B. Atrial Fibrillation in Patients with Acute Pulmonary Embolism: Clinical Significance and Impact on Prognosis. Biomed Res Int 2019;2019:7846291.

5. Aimo A, Giugliano RP, De Caterina R. Non-Vitamin K Antagonist Oral Anticoagulants for Mechanical Heart Valves: Is the Door Still Open? Circulation 2018;138:1356-65.

6. Cain D, Hutson SM, Wallin R. Assembly of the warfarin-sensitive vitamin K 2,3-epoxide reductase enzyme complex in the endoplasmic reticulum membrane. J Biol Chem 1997;272:29068-75.

7. Streif $W$, Andrew $M$, Marzinotto $V$, Massicotte $P$, Chan AK, Julian $\mathrm{JA}$, et al. Analysis of warfarin therapy in pediatric patients: A prospective cohort study of 319 patients. Blood 1999;94:3007-14.

8. Hirsh J, Dalen J, Anderson DR, Poller L, Bussey H, Ansell J, et al. Oral anticoagulants: mechanism of action, clinical effectiveness, and optimal therapeutic range. Chest 2001;119(1 Suppl):8S-21S.

9. Gage BF, Lesko LJ. Pharmacogenetics of warfarin: regulatory, scientific, and clinical issues. J Thromb Thrombolysis 2008;25:4551. 
10. Riley R, Rowe D, Fisher LM. Clinical utilization of the international normalized ratio (INR). J Clin Lab Anal 2000;14:101-14.

11. Shikdar S, Vashisht R, Bhattacharya PT. International Normalized Ratio (INR). 2021 May 10. In: StatPearls [Internet]. Treasure Island (FL): StatPearls Publishing; 2021 Jan.

12. Türk Hematoloji Derneği, Available at: http://www.thd.org.tr/THD_ Halk/?sayfa=kkr. Accessed: February 20,2021

13. Azzam H, Elwakeel H, Awad I, El-Farahaty R, El-Gilany AH, ElSharawy S. VKORC1 and CYP2C9 genotypes in Egyptian patients with warfarin resistance. Blood Coagul Fibrinolysis 2016;27:121-6.

14. Lewis BC, Nair PC, Heran SS, Somogyi AA, Bowden JJ, Doogue MP, et al. Warfarin resistance associated with genetic polymorphism of VKORC1: linking clinical response to molecular mechanism using computational modeling. Pharmacogenet Genomics 2016;26:4450 .

15. Misasi S, Martini G, Paoletti O, Calza S, Scovoli D, Marengoni A et al. VKORC1andCYP2C9 polymorphismsrelatedtoadverseevents in case-controlcohort of anticoagulatedpatients. Medicine 2016;95:e5451.
16. Kirac D, Erdem A, Avcilar T, Yesilcimen K, Guney Al, Emre A, et al. Effects of genetic factors to stent thrombosis due to clopidogrel resistance after coronary stent placement. Cell Mol Biol (Noisy-legrand) 2016;62:51-5.

17. Hosseinkhani Z, Sadeghalvad M, Norooznezhad F, Khodarahmi R, Fazilati M, Mahnam A, et al. The effect of CYP2C9*2, CYP2C9*3, and VKORC1-1639 G>A polymorphism in patients under warfarin therapy in city of Kermanshah. Res Pharm Sci 2018;13:377-84.

18. Dilge Taşkın B, Kula S, Ergün MA, Altun D, Olguntürk R, Tunaoğlu FS, et al. The effect of CYP2C9 and VKORC1 genetic polymorphisms on warfarin dose requirements in a pediatric population. Anatol J Cardiol 2016;16:791-6.

19. Ozer N, Cam N, Tangurek B, Ozer S, Uyarel H, Oz D, et al. The impact of CYP2C9 and VKORC1 genetic polymorphism and patient characteristics upon warfarin dose requirements in an adult Turkish population. Heart Vessels 2010;25:155-62.

20. Al-Eitan LN, Almasri AY, Khasawneh RH. Impact of CYP2C9 and VKORC1 Polymorphisms on Warfarin Sensitivity and Responsiveness in Jordanian Cardiovascular Patients during the Initiation Therapy. Genes (Basel) 2018;9:578 